\title{
PERKECAMBAHAN 4 AKSESI JEWAWUT (Setaria italica (L.) P. Beauv) PADA KONDISI CEKAMAN KEKERINGAN ARTIFISIAL
}

\author{
Septiani Mapikasari ${ }^{1)}$, Adisyahputra $^{2)}$, Reni Indrayanti $^{2)}$
}

${ }^{1}$ Program Studi Biologi FMIPA Universitas Negeri Jakarta (UNJ), Jl. Pemuda No. 10, Rawamangun, Jakarta Timur. Indonesia.

*Corresponding Email: septimafikasari@gmail.com

\begin{abstract}
Developing of jewawut cultivation as an alternative source of carbohydrates is one of the efforts to prevent food insecurity. Drought conditions and the availability of drought-tolerant seeds became one of the problems in the development of jewawut cultivation. The purpose of these experiments were to evaluate jewawut response to drought stress simulations at germination phases and to obtain accessions tolerant to drought stress. Drought stress is performed indirectly (PEG 6000 selective media). The research was done in Laboratory of Physiology of Faculty of Mathematic and Science, UNJ from February until July 2017. The experiments were done with a completely randomized design. Parameters of germination were analyzed with Anova test and continued by Duncan Multiple Range Test (DMRT). Lethal doses of PEG reducing $50 \%$ of germination $\left(\operatorname{LD}_{50}\right)$ were $23,25 \%$, with the quadratic equation $y=1,12-2,72 x$. The results base on germination phase, Buru merah as drought tolerance accessions, Polman merah and Polman kuning as medium tolerance accession, and Buru kuning as susceptible accessions.
\end{abstract}

Keywords: drought tolerance, lethal doses, PEG solution, germination percentage

\section{PENDAHULUAN}

Beras merupakan sumber karbohidrat utama bagi sebagian besar masyarakat Indonesia. Jumlah penduduk Indonesia tahun 2015 mencapai 255,46 juta jiwa, dengan tingkat konsumsi beras rata-rata 124,89 kg/kap/th (BPS, 2015). Jumlah tersebut meningkat dari tahun sebelumnya, yaitu 251,38 juta jiwa penduduk, dengan tingkat konsumsi beras rata-rata 113,72 kg/kap/th (BPS, 2014 ; BPS, 2015). Kebutuhan beras akan mengalami peningkatan seiring dengan pertambahan jumlah penduduk. Sementara itu produksi beras yang sulit untuk ditingkatkan, terutama karena terbatasnya luas areal panen beririgasi, lahan subur yang semakin berkurang, perubahan iklim global, dan faktor produksi lainnya akan berdampak pada persediaan beras dimasa yang akan datang akan mengalami penurunan. Ketergantungan penduduk Indonesia terhadap beras yang sangat tinggi akan menyebabkan terjadinya kerawanan pangan. Menghadapi masalah tersebut maka pengelolaan bahan pangan alternatif merupakan salah satu langkah 
strategis untuk mencegah terjadinya kerawanan pangan, serta menyediakan bahan pangan pendukung program diversifikasi pangan.

Serealia minor jenis Jewawut merupakan komoditi potensial untuk dikembangkan sebagai sumber karbohidrat, dan potensial untuk dikembangkan di lahan sub optimum (kekeringan) (Hidayati \& Fauzia, 2016). Jewawut (Setaria italica (L.) P.Beauv.) adalah salah satu jenis serealia yang merupakan famili Poaceae (Lata et al., 2012). Biji Jewawut digunakan sebagai makanan manusia diberbagai Negara Asia, Eropa bagian Tenggara, dan Afrika Utara, biasanya diolah dengan cara dimasak seperti beras. Biji jewawut mengandung karbohidrat sedikit lebih rendah (73,4 gr) dibandingkan dengan beras (76,2 gr), selain itu jewawut mengandung 9,7 gr protein, 3,5 gr lemak, dan kalsium 28 mg lebih unggul dibandingkan dengan beras (BKPP, 2014).

Upaya pengembangan budidaya tanaman jewawut masih menemukan banyak kendala yaitu kondisi kekeringan dan ketersediaan benih unggul yang toleran kekeringan. Berdasarkan data Balitsereal, (2017) koleksi galur jewawut baru mencapai 20 galur, evaluasi cekaman abiotis utamanya kekeringan masih sedikit, dan program litbang hotong (jewawut) yang sampai saat ini masih bertumpu pada jagung. Maka dari itu dibutuhkan penelitian yang lebih untuk pengembangan jewawut.

Kekeringan atau kekurangan air memberikan dampak buruk bagi pertanian, terutama sektor pangan. Kekeringan merupakan faktor lingkungan utama yang dapat menghambat pertumbuhan tanaman, menyebabkan penurunan hasil, dan bahkan menjadi penyebab kematian tanaman (Kurniasari, 2010 ; Salisbury \& Ross, 1992). Jewawut pada umumnya dapat tumbuh pada lahan-lahan kering pada dataran rendah hingga dataran tinggi (Suharno, 2015). Salah satu langkah yang dapat dilakukan untuk mengurangi tingkat penurunan produksi akibat cekaman kekeringan adalah dengan menanam varietas unggul tanaman jewawut yang toleran kekeringan.

Simulasi cekaman kekeringan dilakukan dengan pemberian larutan PEG (Polietilena Glikol). Penggunaan Larutan PEG bertujuan untuk memperoleh kondisi cekaman kekeringan yang homogen dan dapat dikontrol pada fase perkecambahan. PEG dapat menyebabkan penurunan potensial air secara homogen sehingga dapat digunakan untuk meniru besarnya potensial air tanah (Michel dan Kaufman, 1973). Penggunaan PEG sebagai media selektif untuk simulasi cekaman kekeringan dapat mendeteksi dan membedakan respon tanaman terhadap cekaman kekeringan serta tidak bersifat racun terhadap tanaman (Asay dan Johnson, 1983). Penelitian ini bertujuan untuk mengevaluasi respon jewawut terhadap simulasi cekaman kekeringan pada fase perkecambahan dan memperoleh aksesi jewawut yang toleran terhadap kekeringan pada fase perkecambahan.

\section{METODE PENELITIAN}

Lokasi penelitian dilaksanakan di Laboratorium Fisiologi Tumbuhan, dan Rumah Kaca Program Studi Biologi, FMIPA, Universitas Negeri Jakarta yang berada di kampus B, Rawamangun Jakarta Timur. Penelitian ini dilaksanakan pada bulan Februari-Maret 2017. Metode yang digunakan dalam penelitian ini adalah eksperimen dengan menggunakan desain Rancangan Acak Lengkap Pola Faktorial. Faktor pertama yaitu pemberian larutan PEG, dan faktor kedua yaitu 4 aksesi Jewawut.

\section{BAHAN DAN ALAT PENELITIAN}

Bahan yang digunakan dalam penelitian ini yaitu Larutan PEG 6000, akuades, benih Jewawut (Setaria italica ( L.) P. Beauv.) aksesi Pulau Buru merah, aksesi Pulau Buru kuning, aksesi Polewali Mandar merah, dan aksesi 
Polewali Mandar kuning yang diperoleh dari Laboratorium Fisiologi Tumbuhan, LIPI Cibinong. Peralatan yang digunakan dalam penelitian ini antara lain Gelas piala, gelas ukur, cawan petri, termometer, oven, alat tulis, kertas saring Whatman 42, kapas, dan kamera digital.

CARA KERJA

Uji viabilitas benih jewawut dilakukan dengan merendam benih dalam akuades bersuhu $27^{\circ} \mathrm{C}$, dan $37^{\circ} \mathrm{C}$ selama 6 jam (Yoshida dalam Wibisono, 2015). Benih yang tenggelam dalam akuades tersebut yang kemudian digunakan dalam uji viabilitas benih yaitu sebanyak 50 benih dalam satu cawan petri dengan empat kali ulangan pada setiap aksesi, sehingga total cawan petri yang digunakan sebanyak 32 cawan petri ( 4 aksesi 8 cawan petri untuk setiap aksesi). Uji viabilitas benih dilakukan dengan menggunakan cawan petri yang sudah diberi kapas, dan kertas saring. Sebanyak 10-15 ml akuades ditambahkan ke dalam cawan petri tersebut agar kondisi lembab (Suhaeti,1988). Perhitungan daya kecambah dilakukan hingga 8 hari benih ditanam (Suhaeti,1988; Bassrudin, 1997).

Penentuan dosis Sub-letal PEG 6000 menggunakan biji aksesi Buru merah. Biji tersebut kemudian dikecambahkan dalam larutan PEG (0,5,10,15, dan 20\%), setiap ulangan dengan jumlah 100 benih. Selanjutnya percobaan cekaman kekeringan pada fase perkecambahan. Toleransi terhadap cekaman kekeringan pada fase perkecambahan dilakukan dengan pemberian dosis sub-letal (15\%) PEG 6000. Masing-masing benih jewawut tersebut dikecambahkan dalam petri, tiap ulangan dengan jumlah 100 benih. Sehingga, benih jewawut yang digunakan dalam percobaan ini sebanyak 400 benih untuk masing-masing aksesi.

\section{TEKNIK ANALISA DATA}

Parameter perkecambahan dianalisis dengan uji Anava (analisis variasi) dilanjutkan dengan uji DMRT (Duncan Multiple Range Test). Pengolahan data dilakukan dengan menggunakan program software IBM SPSS v.22.

\section{HASIL DAN PEMBAHASAN}

\section{UJI VIABILITAS BENIH JEWAWUT 4 AKSESI}

Viabilitas benih adalah daya hidup benih yang ditunjukkan melalui proses pertumbuhan benih dan gejala metabolismenya. Potensi viabilitas dapat diketahui melalui persentase daya berkecambah benih. Jewawut aksesi Buru diketahui memiliki masa dormansi yang disebabkan oleh afterripening (Simanjuntak, 2012), maka dari itu dilakukan upaya pematahan dormansi dengan perendaman benih menggunakan akuades suhu $37^{\circ} \mathrm{C}$ (shocking) dan suhu $27^{\circ} \mathrm{C}$ (kontrol).

Kisaran daya berkecambah pada perlakuan tanpa shocking adalah 93-100\%, sementara kisaran daya berkecambah pada perlakuan shocking adalah 97-100\% (Tabel 1, Gambar 1). Pada perlakuan tanpa shocking, persentase daya berkecambah terendah terdapat pada aksesi Polman kuning (93\%), begitu juga pada perlakuan shocking persentase daya berkecambah terendah terdapat pada aksesi Polman kuning (97\%). Adanya peningkatan persentase daya berkecambah aksesi Polman kuning pada perlakuan shocking mengindikasikan bahwa benih tersebut telah mengalami patah dormansi, walaupun berdasarkan hasil uji Anava diketahui bahwa tidak ada perbedaan yang signifikan antara perlakuan shocking dan tanpa shocking terhadap daya berkecambah $(\mathrm{P}>0.05)$.

Perendaman dengan suhu $37^{\circ} \mathrm{C}$ (shocking) mampu menstimulasi perkecambahan benih jewawut aksesi Polman kuning lebih baik. Perendaman dengan suhu tersebut mempengaruhi proses imbibisi, membuat sel mudah menyerap air dan mengaktifkan enzim hydrolase. Enzim hydrolase membantu perombakan cadangan makanan 
pada biji dan pelunakan endosperm sehingga mudah ditembus radikula (Salisbury dan Ross, 1995). Persentase daya berkecambah pada perlakuan shocking adalah $>95 \%$. Oleh karena itu, metode shocking tersebut digunakan pada percobaan selanjutnya, dan 4 aksesi jewawut yang digunakan pada penelitian ini telah mengalami patah dormansi, maka keempat aksesi tersebut dapat disertakan pada percobaan selanjutnya.

Tabel 1. Persentase daya berkecambah benih jewawut 4 aksesi tanpa perlakuan shocking (270C) dengan perlakuan shocking $(370 \mathrm{C})$.

\begin{tabular}{llllll}
\hline \multirow{2}{*}{ Suhu } & \multirow{2}{*}{ Aksesi } & \multicolumn{4}{c}{ Hari berkecambah dan persentase (\%) perkecambahan } \\
\cline { 2 - 6 } & & $1-2$ hari & $3-4$ hari & $5-6$ hari & $7-8$ hari \\
\hline \multirow{3}{*}{ 270C } & Polman Merah & 88.5 & 99.5 & 99.5 & 99.5 \\
& Polman Kuning & 86.0 & 92.0 & 93.0 & 93.0 \\
& Buru Merah & 97.0 & 100.0 & 100.0 & 100.0 \\
& Buru Kuning & 98.5 & 100.0 & 100.0 & 100.0 \\
$370 \mathrm{C}$ & Polman Merah & 92.5 & 100.0 & 100.0 & 100.0 \\
& Polman Kuning & 84.5 & 96.5 & 96.5 & 97.0 \\
& Buru Merah & 94.5 & 100.0 & 100.0 & 100.0 \\
& Buru Kuning & 100.0 & 100.0 & 100.0 & 100.0 \\
\hline
\end{tabular}
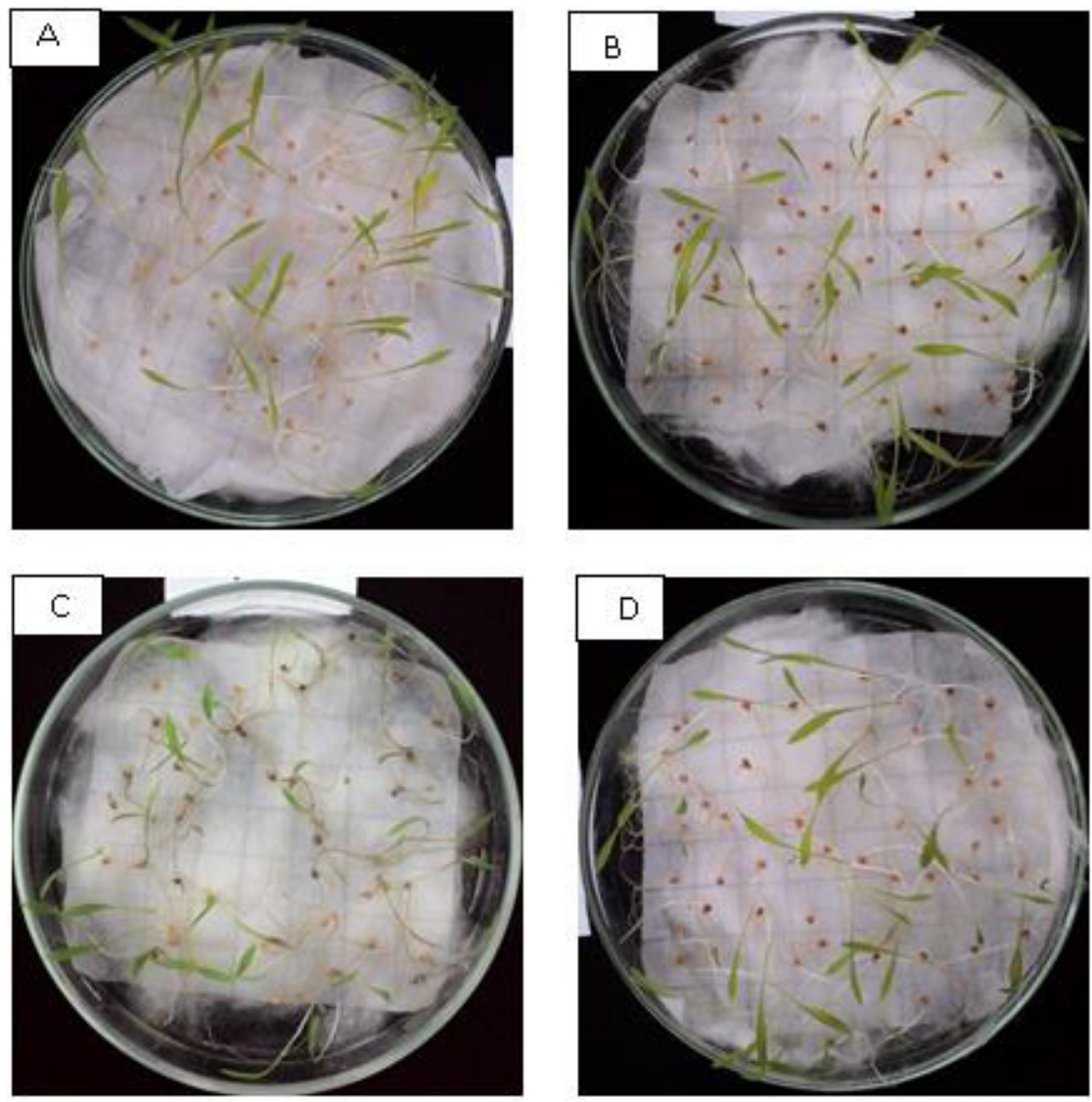

Gambar 1. Perkecambahan benih jewawut: A Buru kuning; B. Buru merah; C. Polman kuning; D. Polman merah pada umur 8 HST. 
PENENTUAN DOSIS SUB-LETAL PEG (0-20\% PEG)

Aksesi Buru merah digunakan dalam percobaan ini karena memiliki persentase daya berkecambah paling baik (100\%). Konsentrasi PEG yang digunakan dalam penelitian ini terdiri dari 0, 5, 10, 15, dan 20\% PEG (0, 5, 10, 15 dan 20 gr PEG/100 ml akuades). Kelima konsentrasi tersebut menghasilkan 5 tingkatan cekaman osmotik (0, -0.3, -0.6, -0.9, dan -1,2 MPa) (Li et al., 2013). Percobaan dilakukan untuk mengetahui dosis sub-letal PEG dengan cara mencari dosis letal PEG sebanyak 50\% terlebih dahulu, artinya dosis PEG yang mampu menghambat daya berkecambah benih jewawut aksesi Buru merah sebanyak 50\%.

Tabel 2. Pengaruh 5 taraf konsentrasi PEG terhadap persentase daya berkecambah jewawut aksesi Buru merah

\begin{tabular}{|c|c|c|c|c|c|}
\hline \multirow{2}{*}{ Aksesi } & \multirow{2}{*}{$0 \%$} & \multicolumn{4}{|l|}{ PEG } \\
\hline & & $5 \%$ & $10 \%$ & $15 \%$ & $20 \%$ \\
\hline Buru Merah & 100.00 & 99.75 & 96.25 & 95.75 & 33.75 \\
\hline
\end{tabular}

Dari kelima taraf yang digunakan, pada taraf 20\% PEG terlihat adanya penurunan daya berkecambah sebanyak lebih dari 50\% yaitu dengan persentase 33.75\% (Tabel 2). Konsentrasi PEG untuk menetapkan batas toleransi terhadap cekaman kekeringan juga ditentukan menggunakan CurveExpert 1.4. Hasil percobaan ini memberikan persamaan kuadratik $\mathrm{y}=\mathrm{a}+\mathrm{bx}$ dengan koefisien data: $\mathrm{a}=1.12, \mathrm{~b}=-2.72 \mathrm{x}$, sehingga persamaan yang diperoleh adalah $y=1.12-2.72 x($ Gambar 2$)$.

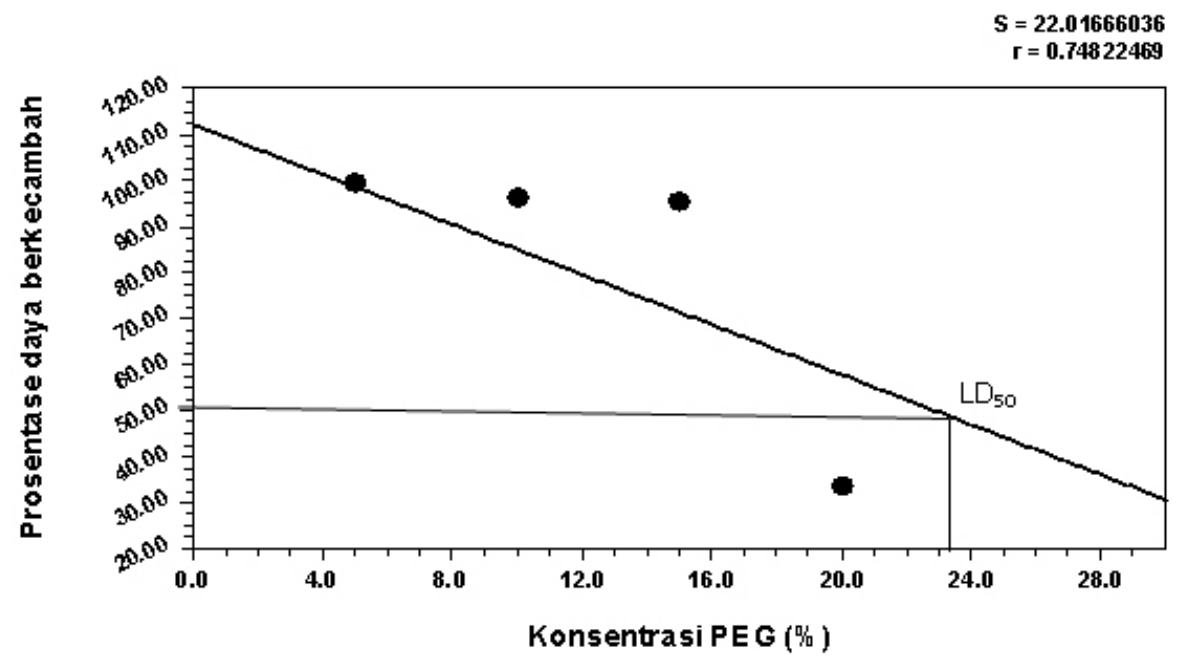

Gambar 2. Penentuan LD50 berdasarkan penurunan persentase perkecambahan jewawut aksesi Buru merah yang diberi perlakuan

Hasil dari persamaan kuadrat $\mathrm{y}=1.12-2.72 \mathrm{x}$ dapat ditentukan bahwa dosis PEG yang mampu menghambat daya berkecambah benih jewawut aksesi Buru merah lebih dari 50\% (LD50) untuk aksesi Buru merah diperoleh pada dosis PEG dengan konsentrasi 23,25\%. Konsentrasi lebih dari 20\% PEG pada percobaan adalah ambang batas bagi keempat aksesi jewawut untuk berkecambah, dan konsentrasi 15\% PEG adalah ambang batas bagi keempat aksesi jewawut untuk berkecambah dengan baik. Hal tersebut sejalan dengan penelitian cekaman kekeringan yang telah dilakukan pada tanaman serealia jenis gandum, dimana reduksi perkecambahan terjadi lebih besar ketika digunakan konsentrasi PEG lebih dari 15\% (Guo et al., 2013). Selanjutnya, PEG dengan konsentrasi 15\% dapat digunakan untuk seleksi toleransi kecambah jewawut terhadap cekaman kekeringan. 


\section{SELEKSI TOLERANSI KECAMBAH UNTUK KEKERINGAN MENGGUNAKAN PEG SUB-LETAL $15 \%$}

Penggunaan larutan PEG dalam penelitian ini ditujukkan untuk membuat kondisi lingkungan tercekam kekeringan secara artifisial. Tolok ukur daya berkecambah akan digunakan dalam menentukan aksesi yang memiliki ketahanan kekeringan secara artifisial. Pada Tabel 3 kisaran rata-rata daya berkecambah keempat aksesi tersebut adalah 60-97\%. Daya berkecambah tertinggi diperoleh aksesi Buru merah (97\%), sementara daya berkecambah terendah diperoleh aksesi Buru kuning (60\%), maka dapat dikatakan bahwa penurunan daya berkecambah keempat aksesi tersebut kurang dari 50\%.

Hasil pengamatan selama 8 hari setelah tanam menunjukkan bahwa persentase daya berkecambah aksesi Buru merah, Polman merah, dan Polman kuning pada larutan 15\% PEG berlangsung baik dengan persentase perkecambahan yang lebih tinggi dibandingkan dengan persentase perkecambahan aksesi Buru kuning. Hal tersebut dapat diketahui bahwa berdasarkan uji Duncan 5\%, efek penghambatan akibat perlakuan cekaman kekeringan terlihat sangat nyata terhadap daya berkecambah.

Cekaman kekeringan sangat mempengaruhi perkecambahan biji, tetapi intensitas respon dan besarnya efek terhadap tanaman bergantung pada spesies atau genotip, umur dan fase perkembangan, tipe organ dan sel, serta kompartemen sub seluler (Bray, 1997). Dalam penelitian ini, cekaman kekeringan memiliki efek negatif terhadap perkecambahan benih jewawut. Secara khusus, persentase perkecambahan menurun dengan peningkatan konsentrasi PEG.

Tabel 3. Pengaruh 15\% PEG terhadap daya berkecambah 4 aksesi jewawut

\begin{tabular}{ll}
\hline Aksesi & Persentase daya berkecambah (\%) \\
\hline Buru kuning & $60.00 \pm 2.00 \mathrm{a}$ \\
Polman kuning & $89.00 \pm 3.00 \mathrm{~b}$ \\
Polman merah & $83.50 \pm 0.50 \mathrm{~b}$ \\
Buru merah & $97.00 \pm 1.00 \mathrm{c}$ \\
\hline Ket : Angka yang diikuti huruf yang sama berarti berbeda tidak nyata pada $a=0.05$ uji Duncan.
\end{tabular}

Proses perkecambahan mencakup peristiwa fisiologis dan morfologis, meliputi imbibisi dan penyerapan air, hidrasi jaringan, pengaktifan enzim, peningkatan respirasi dan asimilasi, pembelahan dan pembesaran sel, serta munculnya embrio (Gardner, 1991). Benih membutuhkan penyerapan air sebelum terjadinya perkecambahan. Potensial air memegang peran utama terhadap proses tersebut. Penyerapan air oleh benih dapat terjadi karena adanya perbedaan potensial anatara air di lingkungan sekitar benih dengan potensial air benih. Penyerapan air oleh benih dapat terjadi karena adanya perbedaan potensial anatara air di lingkungan sekitar benih dengan potensial air benih.

Potensial air di lingkungan benih lebih tinggi dibandingkan dengan potensial air di dalam benih, maka proses penyerapan air oleh benih dapat terjadi. Senyawa PEG mempunyai sub-unit etilen oksida (CH2-O-CH2) pada rantai panjang polimernya. Senyawa tersebut ketika dilarutkan dalan air, maka akan menyebabkan penurunan potensial air. Hal tersebut disebabkan karena sub-unit etilen pada PEG tersebut mampu menarik senyawa $\mathrm{H} 2 \mathrm{O}$ air ke atom oksida sub-unit etilen oksida melalui ikatan hidrogen. Menyebabkan sejumlah air akan terikat oleh senyawa PEG, dan hanya sebagian kecil air yang tersedia untuk perkecambahan. Kondisi kurang tersedianya air pada lingkungan benih akan menyebabkan jumlah air yang dapat diserap benih menjadi semakin rendah dan kemudian menyebabkan reduksi perkecambahan. Kondisi kurang tersedianya air pada lingkungan benih akan menyebabkan jumlah air yang dapat diserap benih menjadi semakin rendah dan kemudian menyebabkan reduksi perkecambahan. 
Perkecambahan benih dalam larutan PEG merupakan metode penyaringan tidak langsung untuk ketahanan terhadap cekaman kekeringan karena tekanan osmotik larutan tersebut jauh lebih tinggi dari tekanan osmotik air murni (Effendi, 2008). Semakin pekat konsentrasi PEG maka semakin banyak subunit-etilen mengikat air sehingga air tersedia menjadi sangat berkurang. Tanaman yang semakin kuat menghadapi kondisi cekaman osmotik tinggi maka tanaman tersebut akan semakin tahan dalam menghadapi cekaman kekeringan. PEG dalam hal ini hanya bersifat membatasi proses imbibisi benih tidak meracuni benih. Hasil penelitian ini juga dapat mengelompokkan keempat aksesi jewawut ke dalam beberapa kandidat. Aksesi Buru kuning menjadi kandidat peka terhadap cekaman kekeringan, aksesi Polman kuning dan Polman merah menjadi kandidat medium toleran terhadap cekaman kekeringan, dan aksesi Buru merah menjadi kandidat toleran terhadap cekaman kekeringan. Aksesi yang toleran tersebut diduga merupakan tanaman yang mampu menggunakan air secara efisien.

\section{KESIMPULAN}

Dosis PEG yang dapat menghambat daya berkecambah sebesar 50\% (LD50) pada benih jewawut aksesi Buru merah adalah pada konsentrasi $23,25 \%$ dengan persamaan kuadrat $y=1,12-2,72 x$, sehingga persamaan kuadrat tersebut dapat digunakan untuk memprediksi dosis letal PEG pada tanaman serealia lainnya. Aksesi Buru merah diidentifikasi toleran, Polman merah dan Polman kuning diidentifikasi medium toleran, dan aksesi Buru kuning diidentifikasi peka terhadap cekaman kekeringan pada fase perkecambahan.

\section{UCAPAN TERIMAKASIH}

Ucapan terimakasih disampaikan kepada staf teknisi Laboratorium Fisiologi Tumbuhan Biologi UNJ, dan staf peneliti Laboratorium Fisiologi Stres Bidang Botani Pusat Penelitian Biologi LIPI Cibinong Science Centre .

\section{DAFTAR PUSTAKA}

[BKPPP] Badan Ketahanan Pangan dan Penyuluhan Provinsi DIY. (2014). [Internet].Tersedia pada: http://bkppp. bantulkab.go.id.

[BPS] Badan Pusat Statistik. (2014). Analisis Sosial Ekonomi Petani di Indonesia Hasil Survei Pendapatan Rumah Tangga Usaha Pertanian Sensus Pertanian 2013. Jakarta: Badan Pusat Statistik.

[BPS] Badan Pusat Statistik. (2015). Survei Sosial Ekonomi Nasional 2015. Jakarta : Badan Pusat Statistik.

[Balitsereal] Badan Penelitian dan Pengembangan Pertanian. (2017). Jewawut, alternatif sumber pangan sehat.. [Internet]. Tersedia pada: $\underline{\text { http://balitsereal.litbang.pertanian.go.id }}$

Bray, E. A. (1997). Plant responses to water deficit. Trend in Plant Sci. 2:48-54.

Effendi, Y. (2008). Kajiam Resistensi Beberapa Varietas Padi Gogo (Oryza Sativa L.) Terhadap Cekaman Kekeringan. [Tesis]. Surakarta : Program Pasca Sarjana Universitas Sebelas Maret Surakarta.

Gardner F. (1991). Fisiologi Tanaman Budidaya. UI Press, Jakarta.

Guo, R., Wei P. H., Dao, Z.G., Xiu, L.Z., and Feng, X.G. (2013). Effect of water stress on germination and growth of wheat, photosynthetic efficiency and accumulation of metabolites. Soil Processes and Current Trends in Quality Assessmen. http://dx.doi.org/10.5772/51205. 
Hidayati, N., dan Fauzia, S. (2016). Evaluasi Lima Aksesi Jewawut Lokal [Setaria italica (L.) P.Beauv]: Karakter Pertumbuhan dan Responnya Terhadap Pemupukan. Prosiding SemABio. Hal: 232.

Kurniasari, A. M., Adisyahputra, dan Rosihan, R. (2010). Pengaruh Kekeringan pada Tanah Bergaram NaCl terhadap Pertumbuhan Tanaman Nilam. Bul, littro. 21(1): 18-27.

Lata. C., Sarika, G., and Manoj, P. (2012). Foxtail millet: a model crop for genetic and genomic Studies in bioenergy grasses. Critical Reviews in Biotechnology , 2012; Early Online: 1-16.

Li, H., Xiaoshong, L., Daoyuan, Z., Huiliang, L., dan Kaiyun, G. (2013). Effect of drought stress on the seed germination and early seedling growth of the endemic desert plant Eremosparton songoricum (Fabaceae). Excli. 12:89-101.

Salisbury, F.B. and C.W. Ross. (1992). Plant Physiology. 4rd Ed. Wadsworth Publishing Company. California.

Salisbury, F. B. dan C.W. Ross. (1995). Fisiologi Tumbuhan. Jilid I. Bandung : Penerbit ITB, Bandung. 241 hal.

Simanjuntak, L. N. (2012). Studi Afterripening dan Teknik Pematahan Dormansi Benih Buru Hotong (Setaria italica (L.) Beauv.) [Skripsi]. Bogor: Institut Pertanian Bogor.

Suhaeti, T. (1988). Metode Pengujian dan Perawatan Mutu Benih. Pusat Penelitian dan Pengembangan Hutan dan Proyek Pendidikan dan Latihan dalam Rangka Peng-Indonesiaan Tenaga Kerja Pengusahaan Hutan. Bogor, pp. 32.

Suharno., Supeni, S., Verena, A., dan Rosye, H. R. T. (2015). Usaha Domestikasi Tumbuhan Pokem (Setaria italica (L.) Beauv) Masyarakat Lokal Pulau Numfor, Kabupaten Biak Numfor Sebagai Upaya Menunjang Ketahanan Pangan Nasional. J. Manusia \& Lingkungan. 22(1): 73-83.

Wibisono, K. (2015). Seleksi Toleransi Padi Rawa Terhadap pH Rendah Dan Pirit Tinggi Pada Fase Vegetatif Awal [Skripsi]. Jakarta: Universitas Negeri Jakarta.

Yoshida, S. (1981). Fundamentals of rice crop science. The International Rice Research Institute. Philippines. Dalam: Wibisono, K. 2015. Seleksi Toleransi Padi Rawa Terhadap pH Rendah Dan Pirit Tinggi Pada Fase Vegetatif Awal [Skripsi]. Jakarta: Universitas Negeri Jakarta. 